\title{
The Unequal Burden of War: The Effect of Armed Conflict on the Gender Gap in Life Expectancy
}

\author{
Thomas Plümper and Eric Neumayer
}

\begin{abstract}
Most combatants in armed conflict are men, so naturally men are the major direct victims of military operations. Yet armed conflicts have important indirect negative consequences on agriculture, infrastructure, public health provision, and social order. These indirect consequences are often overlooked and underappreciated. They also affect women-arguably more so than men. This article provides the first rigorous analysis of the impact of armed conflict on female life expectancy relative to male. We find that over the entire conflict period, interstate and civil wars on average affect women more adversely than men. In peacetime, women typically live longer than men. Hence, armed conflict tends to decrease the gap between female and male life expectancy. For civil wars, we also find that ethnic wars and wars in "failed" states are much more damaging to women than other civil wars. Our findings challenge policymakers as well as international and humanitarian organizations to develop policies that tackle the large indirect and long-term negative health impacts of armed conflicts.
\end{abstract}

There can be no doubt that armed conflict directly kills, injures, and harms more men than women in that combatants are predominantly male. ${ }^{1}$ Yet, armed conflict has many negative indirect consequences on health and survival. Indeed, there are good reasons to presume that the indirect consequences of conflict are much more important in many cases than the direct casualties. Lacina and Gleditsch concur that direct conflict fatalities do "not provide a remotely adequate account of the true human costs of conflict." ${ }^{2}$ Most victims of war die in silence. We will argue

Equal authorship. We are grateful for helpful suggestions by Andrew Mack, Håvard Hegre, David Hugh-Jones, Lisa Martin, and the anonymous referees. Eric Neumayer acknowledges financial assistance from the Leverhulme Trust and Thomas Plümper financial assistance by the European Commission-DG Research Sixth Framework Program (CIT-2-CT-2004-506084). Data and do-files to generate the results are available on request.

1. The World Health Organization (WHO) estimates the share of females among direct war fatalities to fall between as low as 9.9 percent in 2004 and up to 42 percent in 1998 (WHO various years). The WHO mortality figures have been heavily criticized as being unreasonably inflated (Human Security Centre 2005). It is unclear, however, whether this criticism affects the share of female mortality. In any case, a higher share of men among direct war mortality is plausible.

2. Lacina and Gleditsch 2005, 7.

International Organization 60, Summer 2006, pp. 723-754

(C) 2006 by The IO Foundation.

DOI: $10.1017 / \mathrm{S} 0020818306060231$ 
in this article that women are likely to suffer most from the indirect consequences. Our estimation results show that on average women are overall more negatively affected by armed conflict than men, suggesting that the indirect consequences are stronger than the direct effects.

The indirect effects of militarized conflicts ${ }^{3}$ result from, among others, reduced access to food, hygiene, health services, and clean water-and by lifting the thin veil of civilization. Women suffer more severely from the damage to the health and other infrastructure and the wider economic damage as well as from displacement and dislocation during and after conflict. The breakdown of social order and the ensuing brutalization fuels male aggression against women, who suffer from sexual violence both within and outside their domestic household. Until recently, no particular attention was paid to the gender-specific aspects of the negative impacts of violent conflict. Recent reports by the United Nations (UN) General Secretary to the Security Council, the UN Development Fund for Women, and the International Committee of the Red Cross have tried to spotlight the issue. ${ }^{4}$ Ours is the first serious attempt at testing rigorously and directly whether armed conflict does indeed affect women's survival chances more severely than that of men.

Specifically, this article analyzes the impact of militarized conflict on the so-called gender gap in life expectancy, which we define as the ratio of female to male life expectancy at birth (in most countries women live longer than men in peacetime such that the ratio is above unity). ${ }^{5}$ We study whether armed conflict-international and civil war-decreases this ratio. In brief, we find that on average and given the sample that we analyze, armed conflict decreases the ratio of female to male life expectancy at birth. Consequently, armed conflict appears to narrow rather than widen the gender gap in life expectancy. Yet we also find that civil wars differ in respect to their impact on the gender gap in life expectancy. Specifically, nonethnic civil wars have no effect on the gender gap, whereas in ethnic civil wars women seem to be the prime victims and particularly so if the ethnic conflict takes place in a "failed" state.

Despite a rise in quantitative gender-analytical studies in recent years, no one has yet rigorously analyzed the uneven effect that armed conflict has on men and women. Instead, existing scholarship has focused on whether gender inequality affects the likelihood of using violence in intra- and interstate conflict. ${ }^{6}$ Similarly, despite the fact that armed political conflict has some obvious consequences on public health, mortality, and life expectancy, surprisingly few conflict studies have

3. We use the terms "armed conflict," "militarized conflict." and "war" interchangeably.

4. See UN 2002; UNDFW 2002; and ICRC 2001.

5. The gender gap in life expectancy is usually measured as the absolute difference between female and male life expectancy, rather than the ratio between the two. For reasons explained below, this absolute difference can be a misleading indicator. We stress, however, that our results uphold even if we defined the gender gap as the absolute difference.

6. See Marshall and Ramsey 1999; Caprioli 2000, 2003, and 2005; Caprioli and Boyer 2001; and Regan and Paskeviciute 2003. 
tried to estimate these effects systematically and rigorously. Indeed, we know of only four relevant studies. ${ }^{7}$ These analyses report a significant negative impact of international and civil wars on life expectancy or disability-adjusted life years. None of these studies directly analyzes the gender gap in life expectancy, however.

The remainder of this article is organized as follows. The first section explains how our study relates to two strands of literature in international relations, namely, gender studies and studies on the health consequences of conflict. The second section provides an explanation of why militarized conflicts should have an influence on the gender gap in life expectancy. The third section discusses the research design of our quantitative study. The fourth section presents the results; and the final section concludes.

\section{Link to Existing Literature}

Our study relates to two important strands of literature in international relations (IR). First, our analysis is located in an emergent strand within IR that employs gender as an analytical category. This means that we try to explain the differential impacts of armed conflict on men and women not merely by recourse to biological differences, but also by tracing the different vulnerabilities that derive from the social roles men and women assume, voluntarily or involuntarily. As Moser has argued, a gender analysis assists in understanding why men and women as social actors and with differential access to resources are differentially affected by violence. ${ }^{8}$ Taking gender seriously also means that despite focusing on the harm that armed conflicts impose on women, we must not ignore the violence and harm suffered by men as either combatants or civilians. In certain contexts, noncombatant men can be singled out for massacres, as happened in Rwanda and Yugoslavia, at the same time as large-scale sexual and other abuse and violence is inflicted on women. ${ }^{9}$ Our analysis will show that women on average suffer more from the indirect and long-term consequences of armed conflict, which calls for much greater attention being paid to these effects. It does not, however, justify the neglect of civilian men in humanitarian crisis evacuations, which can go contrary to the very aim of evacuating those most vulnerable, as Carpenter has forcefully argued in the context of evacuations in the Yugoslav conflicts. ${ }^{10}$ Such ill-informed policy decisions are probably attributable to the preponderance of gender stereotypes that see men only and exclusively as perpetrators and women only and exclusively as victims of violence. ${ }^{11}$ Carpenter shows that such stereotypes are often strategically 2005.

7. See Davis and Kuritsky 2002; Ghobarah, Huth, and Russett 2003 and 2004; and Li and Wen

8. Moser 2001.

9. See Jones 1994, 2000, 2002, and 2004; and Carpenter 2003.

10. Carpenter 2003.

11. Carver 2004. 
employed by humanitarian organizations to raise and mobilize support for their operations. ${ }^{12}$

Taking gender seriously as an analytical concept does not imply that we subscribe to the feminist IR agenda of active engagement in a political struggle for the empowerment of women. ${ }^{13}$ Carpenter has lamented that mainstream IR scholars have been largely silent on gender, thus depriving knowledge on gender of nonfeminist insights. ${ }^{14}$ As mainstream IR scholars, we aspire to correct this potential bias to some extent by directly focusing on gender for an important aspect of IR, namely, the consequences of the use of armed violence. Our main question can be answered by employing traditional IR methods of formulating and testing hypotheses using procedures that are publicly known and replicable. ${ }^{15}$ Our analysis thus complements quantitative gender-analytical IR studies undertaken by scholars, some of which would regard themselves as feminists, whereas others would not. ${ }^{16}$ The main difference to these studies is that we quantitatively estimate the gender-specific effects of armed political conflict, whereas existing studies address the impact of gender inequality on the use of violence in interstate and intrastate conflict. ${ }^{17}$

Second, our analysis directly relates to studies that have addressed the broader and long-term public health consequences of armed conflict. Our original contribution is that we look at these consequences with a gender-analytical perspective. Three recent articles have demonstrated the seemingly obvious: international and civil wars reduce the quality of life of broad parts of the population and reduce the mean life expectancy of the country that is engaged in militarized conflicts. For example, Ghobarah, Huth, and Russett study cross-national variation in 1999 data on disability-adjusted life years (DALYs). ${ }^{18}$ DALY is a new measure that has been estimated by the World Health Organization (WHO) starting in the late 1990s. DALYs are calculated for individual major disease categories and reflect the years of life lost due to death in the fatal cases as well as the expected disability caused by a disease in nonfatal cases. They are the most important input for estimating health adjusted life expectancy (HALE), which adjusts nominal life expectancy for expected years with disability. Specifically, Ghobarah, Huth, and Russett regress DALYs in 1999 on estimated fatality figures from civil wars in the period 1991 to 1997 as well as a range of control variables. The results are interpreted as the long-term effects of civil wars. They estimate that around 12 million DALYs were lost in 1999 due to civil wars in the same countries plus perhaps another 3 million DALYs in neighboring countries, which is close to twice WHO's estimate of direct

12. Carpenter 2005.

13. As outlined, for example, by Tickner 1997, 2001, and 2005.

14. Carpenter 2002, 153.

15. Keohane 1998, 196.

16. See Caprioli 2004 for an overview.

17. See Marshall and Ramsey 1999; Caprioli 2000, 2003, and 2005; Caprioli and Boyer 2001; and Regan and Paskeviciute 2003.

18. Ghobarah, Huth, and Russett 2003 and 2004. 
and immediate loss of DALYs from all armed conflicts in $1999 .{ }^{19}$ Looking at individual disease categories broken down by gender and age group, Ghobarah, Huth, and Russett find that infectious diseases and transport accidents are the categories for which there is most consistent evidence for an effect of civil war. They also find that past fatality figures had a statistically significant effect on more disease categories for women than for men and for more categories for children than chance would predict. This is interpreted as evidence that women and children are affected most by the long-term consequences of conflict, which is problematic, however, without detailed information on the number of fatalities in each disease category, broken down by age and sex. Only an aggregate measure of mortality such as the gender-specific life expectancy we use is capable of telling us whether in total more women were killed than men or were killed at an earlier age than men by the combined direct and indirect effects of war.

Davis and Kuritsky use panel data to estimate the effect of armed conflict on life expectancy and other health indicators in sub-Saharan Africa over the period 1980 to $1997 . .^{20}$ They estimate that life expectancy in countries, which experienced a conflict with at least 1,000 deaths, on average declined by about one year. This increases to an estimated 2.35 years for severe conflicts, defined as conflicts in the course of which at least 1 percent

A recent study by $\mathrm{Li}$ and Wen analyzes the effects of an armed conflict dummy as well as of past conflict duration on adult mortality (people aged fifteen to sixtyfour). ${ }^{21}$ While their main focus is on quantifying the effects of wars on mortality rather than on the gender differences in mortality, they find that men typically suffer higher immediate conflict mortality, whereas men and women are affected to about the same extent by the long-term effect (as proxied by past conflict duration). One might think that, in combination, this would imply that men are more adversely affected by armed conflict than women, thus contradicting the main result of our study. However, for at least two reasons $\mathrm{Li}$ and Wen's results do not allow such a conclusion (and we stress that they themselves do not draw such a conclusion). First, the estimated coefficients for both conflict dummies and past conflict duration on male mortality are not statistically significantly different from the estimated coefficients on female mortality. Second, and more importantly, by focusing on adult mortality, they leave out children and the elderly; thus no conclusions on the differential gender effect of armed conflict on the entire population can be drawn.

Several more papers have studied variation in life expectancy, mostly in a crossnational setting, but without addressing the impact of armed conflict. ${ }^{22}$ These studies inform our choice of control variables (see the section on research design below).

19. Murray 1994 discusses the technical basis of DALYs.

20. Davis and Kuritsky 2002.

21. Li and Wen 2005.

22. See Hertz, Hebert, and Landon 1994; Williamson and Boehmer 1997; Kennelly, O'Shea, and Garvey 2003; and Bossuyt et al. 2004. 
In particular, they point toward the importance of controlling for per capita income, basic education, and the participation of women in economic life. However, little social science research has specifically addressed female life expectancy, let alone the gender gap in life expectancy. ${ }^{23}$

\section{Conflict and the Gender Gap in Life Expectancy}

Wars kill, before, during, and after military operations take place. Before the actual conflict starts, military expenditures often rise and drag scarce resources away from health services and medical care. During conflict, the most obvious victims are the casualties directly attributable to conflict. Both soldiers and civilians suffer morbidity and mortality inflicted by wounds. The direct effects of combat and military operations are likely to affect men more. Because most soldiers in most armies are male, men should be more severely affected by the direct causes of war than women. The more civilians are directly killed by military operations, the more women will be directly killed as well. ${ }^{24}$ But there is no reason to presume that more women than men are killed in combat. Yet the major losses of life and other negative public health effects can be the indirect consequences of armed conflict. Indirect effects of wars on life expectancy result from various sources. Armed conflict both generates conditions for increased morbidity and mortality and weakens the capacity for dealing with the increase in adverse health conditions. ${ }^{25}$

The many indirect negative consequences on health and mortality are likely to affect men and women differently, partly because of biological reasons, but mainly because of variation in the socioeconomic status of men and women. In the following subsections, we identify three indirect effects that account for the fact that militarized conflicts unevenly affect men and women. We refer to these effects as the economic damage effect, the displacement effect, and the sexual violence effect. Clearly, these effects are not independent but may easily reinforce one another, thereby rendering the situation more dramatic for the people involved. Keeping these interaction effects in mind, it is for explanatory purposes that we discuss the three effects separately and in turn. After this discussion, the theoretical section concludes with a discussion of why the identified effects can be expected to be particularly strong when armed conflict has ethnic roots or takes place in a country in which the central political order has collapsed.

23. Williamson and Boehmer 1997.

24. It is difficult to estimate reliably the share of civilian victims of armed conflict. The often quoted statistic that this share increased from 14 percent during World War I to 67 percent in World War II, reaching 75 percent and 90 percent during the armed conflicts of the $1980 \mathrm{~s}$ and $1990 \mathrm{~s}$ (which were predominantly civil wars), respectively, is based on shaky empirical evidence, as Murray et al. 2002, $346 \mathrm{f}$, have pointed out.

25. Foege 1997. 


\section{The Economic Damage Effect}

Armed conflicts affect all aspects of life, including the economy. They often lead to the destruction of agricultural systems causing food shortages. Food shortage leads to rising food prices, which in crucial cases may cause famines. As observed by Drèze and Sen, famine is a problem of food distribution and poverty rather than a problem resulting from an absolute lack of food. ${ }^{26}$ In addition to damage to agriculture and systems of food distribution, armed conflict damages the basic infrastructure such that access to electricity, safe water, and sanitation is impeded. In many conflicts, the warring parties actively and explicitly target the infrastructure, with the consequence that drinking water, sewage and sanitation facilities, power plants, communication lines, and the basic health infrastructure are severely damaged and cease to function reliably. This strategy is supposed to lead to chaos and social disorder, destabilizing the opposite party. It is not entirely new, as age-old military strategies have included blockading food, burning crops, and introducing infectious diseases to cities under siege. ${ }^{27}$ However, King and Martin argue that advances in military strategy and technology have led to "increasingly severe public health consequences of war," ${ }^{28}$ while Garfield and Neugut state that "modern weaponry and tactics extend the battlefield to the entire society, including civilians." 29

Particularly problematic to the civilian population is damage to the medical and health care infrastructure. Hospitals and pharmacies are destroyed; doctors and nurses have fled the country or have been killed. Economic collapse and a shortage of public funds lead to severe underfunding and underprovision of both private and public health services. Even emergency medical problems fail to be attended to on time, while fundamental prevention policies with long-term beneficial health effects such as immunization and monitoring programs are simply terminated. For example, a WHO report on the medical situation in Bosnia between 1992 and 2000 concludes: "Pharmaceutical supply during the war and postwar period was mostly channeled through humanitarian aid programs, covering up to $70 \%$ of supplies-according to some estimates. In a large number of cases, this heavily influenced the choice of therapy, which often depended on the kind and quantity of drugs available." ${ }^{30}$ With other countries less easy to reach and with some militarized conflicts being less present in the media, one should expect these problems to mount. However, not only does the provision of health services decline in conflicts, often medical equipment is destroyed. In the same study, the WHO estimates that about 40 percent of medical equipment was out of use during and after the civil war in Bosnia. As a consequence, prices of medicines and

26. Drèze and Sen 1990.

27. Ashford and Huet-Vaughn 1997.

28. King and Martin 2001, 2.

29. Garfield and Neugut 1997, 35. See also Roberts et al. 2004.

30. WHO 2004, 1. 
health services increase so rapidly that the poorer parts of the population can no longer afford medication and are often doomed to die even from otherwise trivial diseases.

With agricultural systems as well as infrastructure damaged, it is no wonder that armed conflicts have a significant effect on average income levels and the economic growth rate. Estimates of the effect of international and civil war on per capita income and the growth rate typically find a significant and robust negative influence..$^{31}$ Collier estimates that per capita income declines at an average annual rate of 2.2 percent relative to its counterfactual during civil wars. ${ }^{32}$ This is the average effect of civil war on per capita income. In some cases, and with civil wars sometimes lasting decades rather than years, the economic damage can be far more severe. For instance, the per capita income in Nicaragua at the onset of the civil war was $\$ 4,276$. At the end of the civil war, per capita income had declined to $\$ 1,913$, which represents an annual decline in per capita income of about 6.5 percent-compared to the average growth rate of 2.5 percent after the civil war, the relative loss in wealth was almost 10 percent per year. During the Nicaraguan civil war, the ratio of women's to men's life expectancy increased between 1978 and 1979 (indicating that most combatant victims were male) but declined in the later years-probably indicating that the indirect losses of the civil war outnumbered the direct losses and that most indirect victims were female.

In addition to loss in average incomes, wars influence the absolute and relative price levels. The majority of the population, for which income does not keep up with inflation, has increasing difficulties in meeting their basic needs. Price increases are most severe for goods for which demand reacts least elastically on price increases-in other words: goods that are most desperately needed: clean water, food, electric power, and medication.

Why is the economic damage caused by armed conflict likely to affect women more than men? Women are likely to suffer more from an increase in food prices and famines than men. For physiological reasons, women are particularly susceptible to vitamin and iron deficiencies in diets. In addition, in male-dominated societies, males get priority in food distribution at the expense of girls and women. The decline in basic health care hits women more because of their specific reproductive roles. Damage caused to the health infrastructure reduces obstetrical care and increases the number of miscarriages as well as maternal and infant mortality. ${ }^{33}$ For example, a recent study by the International Red Cross indicated an extraordinarily high maternal mortality rate of 3 percent in the rebel-controlled areas of civil war-ridden Congo. The high levels of maternal mortality are associated with early sexuality and motherhood (the teenagers of less than twenty years contribute 20 percent to the total fertility), too many pregnancies and births (the total is esti-

31. See Collier 1999; Murdoch and Sandler 2002; and Gyimah-Brempong and Corley 2005.

32. Collier 1999.

33. Ashford and Huet-Vaughn 1997. 
mated at seven children per woman), unspaced pregnancies (the average period between two births is less than two years), motherhood at a late age, and induced clandestine abortions associated with unwanted pregnancies that affect 30 percent of the teenagers. ${ }^{34}$ This poor health care situation in civil war-torn regions already accounts for a severe drop in the life expectancy of women in the Congo.

More generally, a significant decline in purchasing power will affect women differently than men because in many cultures men receive preferential access to resources. When resources become scarcer, then the part of the population suffering from discrimination is necessarily hit even harder. Many of the negative effects of armed conflict on women are thus not due to biological reasons, but are due to what Carpenter calls "preexisting gendered social structures." ${ }^{35}$ For example, the extra burden of securing water, food, and wood for heating purposes, which comes on top of caring and nurturing their family, often falls on women and exposes them to many dangers. Thus in societies where female discrimination is widespread even during peacetime, women will suffer particularly strongly from the destructive power of violent conflict. ${ }^{36}$

\section{The Displacement Effect}

Armed conflict often dislocates people from their usual homes, crowding them into remaining shelters. Worse still, often they have to leave their home cities or villages and have to seek refuge in makeshift refugee tent camps-either in foreign countries across the border or as internally displaced persons (IDPs). As a consequence, infectious diseases such as diarrhea, measles, acute respiratory diseases, and malaria, but also sexually transmitted diseases including HIV/AIDS, spread more easily, often turning into epidemics. Weakened and fragile individuals die more easily from diseases they might have survived in better physical and mental conditions.

Health conditions are particularly poor in refugee camps. Toole reports mortality rates from refugee camps that are up to 100 times higher than the normal mortality rate in the affected country. ${ }^{37}$ IDP refugee camps can be particularly severely hit if they are geographically close to zones of ongoing conflict as people are either directly affected by the fighting or the ongoing conflict delays and impedes assistance. Data disaggregated according to gender is rare, but Toole reports data from a Burmese refugee camp in Bangladesh where female infants were twice as likely to die than male infants and the mortality rates of females above the age of five was 3.5 times higher than that of males. ${ }^{38}$ While we do not argue that women

34. UN 2003, 41.

35. Carpenter 2004, 243.

36. See ICRC 2001; and UN 2002.

37. Toole 1997.

38. Women are not only more likely to die from the dire conditions in refugee camps, they also possibly account for the largest average share of camp population. 
would have been better off if they had not fled into refugee camps, there can nevertheless be little doubt that the mortality differences in these camps can be significant. This situation can become exacerbated if culturally binding norms allow certain forms of female hygienic care only under conditions of privacy and separation from men, which are often impossible to maintain in refugee camps.

Though there is little reason to formulate a deterministic negative influence of displacement in militarized conflicts on the gender gap in life expectancy, we believe that the probabilistic argument is fairly strong. With an increased number of displaced persons, the gender gap in life expectancy is likely to decline, because of the health conditions in refugee camps and the possible overrepresentation of women in these camps.

\section{The Sexual Violence Effect}

A third effect is due to the targeted infliction of violence on women as part of a "gender ideology." ${ }^{39}$ Girls and women become the victims of sex trafficking and are forced to serve in military brothels or endure other forms of sexual slavery. Though all figures must be treated with caution, estimates amount to organized and systematic rape of at least 20,000 women and girls by the Serbian military and the murder of many of the victims during the civil war in Bosnia. ${ }^{40}$ At the same time, there is evidence that young Bosnian and, later on, Kosovo Albanian males fit for battle were specifically targeted for killing by Serbian militia to extinguish armed resistance. ${ }^{41}$ Still, women have been targeted and victimized to such an extent during the Balkan conflicts that so-called gender crimes form part of the crimes against humanity prosecuted by the International Criminal Tribunal for the Former Yugoslavia (ICTY) ${ }^{42}$ Similarly, Article 7 of the newly established Rome Statute of the International Criminal Court (ICC) includes "rape, sexual slavery, enforced prostitution, forced pregnancy, enforced sterilization, or any other form of sexual violence of comparable gravity" among crimes against humanity open to prosecution.

Reports on systematic rapes and murders of women in relation to war are by no means limited to Bosnia. In other conflicts, particularly in sub-Saharan Africa, rape was used with the intention of spreading HIV/AIDS and other sexually transmitted diseases. Injuries to vaginal tissue is a common consequence of rape and renders affected women much more susceptible to sexually transmitted diseases. In principle, women should enjoy special protection in armed conflict. The Geneva Convention relative to the Protection of Civilian Persons in Time of War from 1950 requires that civilians "shall be at all times humanely treated, and shall be

39. Carpenter 2004, 237.

40. Stiglmayer and Faber 1994.

41. See Carpenter 2002; and Jones 2004.

42. See Askin 1997; and UN 2002. 
protected especially against acts of violence," while women "shall be especially protected against any attack on their honor, in particular against rape, enforced prostitution, or any form of indecent assault" (Article 27). However, many warring parties simply do not obey their obligations under the Geneva Convention and other humanitarian law, which has prompted the UN's Security Council to call on "all parties to armed conflict to take special measures to protect women and girls from gender-based violence, particularly rape and other forms of sexual abuse, and all other forms of violence in situations of armed conflict." 43

\section{The Role of Ethnicity and Collapse of Political Order}

The economic damage effect, displacement effect, and the sexual violence effect can be expected to be particularly strong where armed conflict takes place in a country where the political order has collapsed or where conflict has ethnic roots. A collapse of political order almost by definition means that the central government is no longer capable of providing even the most basic infrastructure and other public goods, not least because it no longer commands over an effective tax system. ${ }^{44}$ Without being able to raise sufficient revenues, the government cannot combat imminent social catastrophes, even if it is willing to do so. Often, civil wars are the reason for a country to develop into a failed state, but it is as important to note that civil wars also tend to be more dirty and intense in failed states. Collapse, disintegration, and armed conflict have occurred in the former Soviet Union, the Balkans, the Caucasus, and Central Africa. In all instances, dozens of political entities emerged, in which self-appointed political leaders struggle among each other and with entities of overlapping claims. As a consequence, failed states can no longer perform basic functions such as education, security, or governance. In these countries, civil wars do not take place between insurgents and government troops, but between different paramilitary groups competing for political control of the country or particular regions. Such a civil war between various warlords, whose prime interest is mostly in arms and drug trafficking for short-term profit maximization, often turns out to cost many more civilian victims than militarized conflicts between the governments and groups that aim at taking over political control.

In the burgeoning literature on failed states, Sierra Leone often serves as an example. ${ }^{45}$ Between the mid-1970s and the late-1990s, government revenues declined from approximately $\$ 250$ million to less than $\$ 10$ million. In some failed states such as Somalia, civil disorder ultimately led to famine as food distribution systems broke down. More generally, eight of the ten countries that have the high-

43. UN 2000, par. 9.

44. Rotberg 2002 and 2004.

45. See Reno 2003; and Krasner 2004. 
est share of undernourished population according to Food and Agriculture Organization (FAO) data-Afghanistan, Angola, Ethiopia, Somalia, Sudan, Mozambique, Liberia, and Sierra Leone-frequently went through cycles of autocratic government, ethnic conflict, and political failure. ${ }^{46}$

Ethnic conflict also increases the likelihood that governments will treat foreign help with political reservations, even if the emergency is caused by natural factors. After the devastating tsunami in December 2004 that caused deaths in eleven countries, the Indonesian government was most reluctant to accept foreign assistance even though the province Banda Aceh, location of a civil conflict with ethnic roots, was hit harder than any other coastal strip around the Indian Ocean. This behavior mirrors the dismissive policies of the Sudanese government during the ongoing civil war in Darfur, which also has ethnic roots. The Sudanese government not only denied carrying out military operations against the rebels, but also strongly opposed humanitarian intervention by the UN, while the Janjaweed militias have been reported of killing civilians, mass rape of women, and looting property.

Conflicts in failed states are also likely to generate higher numbers of refugees and internally displaced people because the central authority can no longer guarantee anything resembling security in many areas. ${ }^{47}$ Conflicts with ethnic origin can also be expected to generate higher refugee flows because the very intention of warfare is often the ethnic cleansing of certain regions (if not the whole country) from other ethnic groups. Neumayer reports a strong effect of civil and ethnic wars as well as collapse of state authority on asylum migration to Western Europe, which is likely to be highly correlated with refugee flows to neighboring countries as well as internal displacement. ${ }^{48}$ Davenport, Moore, and Poe find that ethnically motivated genocidal conflicts drastically increase the number of refugees and internally displaced persons. ${ }^{49}$ Of the seven countries with the highest number of internally displaced to resident populations in 2002 according to the Norwegian Refugee Council-Azerbaijan, Lebanon, Burundi, Sierra Leone, Bosnia Herzegovina, Sudan, and Angola - all of them experienced a militarized ethnic conflict, and in five countries the political control collapsed. ${ }^{50}$ Hence, five of these seven countries combined ethnic conflicts with a breakdown of political control; and while Azerbaijan and Sudan maintained political control, one can doubt whether this control extended over the entire territory of the country. On average, the relation between the ethnic roots of conflict, state failure and the number of displaced persons appears to be quite strong.

The sexual violence effect of armed conflict is facilitated by the fact that many militarized conflicts lead to a partial or complete collapse of political order. The

46. FAO 2005.

47. Rotberg 2002 and 2004.

48. Neumayer 2005.

49. Davenport, Moore, and Poe 2003.

50. Norwegian Refugee Council 2002, 5. 
absence of a rule of law hits the vulnerable most severely. At the same time, reports on systematic rapes and rape-related murder of women, forced impregnation, and forced abortion are particularly abundant during ethnic wars. In such conflicts, sexual violence serves as a means of ethnic cleansing, terrorization, and humiliation, not only of the violated women, but also the men of the same ethnic group who are forcibly demonstrated their failure to protect "their" women. Sexual violence against women thus serves as an important signal "from man to man," wounding the men of the opposing ethnic group in their masculinity by marking them as incompetent. ${ }^{51}$ Inflicting sexual violence on women from other ethnic groups also serves as an assault on "the honor of the community and for defiling women who are entrusted by the community to maintain the purity of lineage." 52 The mere threat of widespread rape is often enough to prompt women and their families to leave certain places and flee elsewhere, as happened in the Kosovo, and can thus be employed as a means of ethnic cleansing. ${ }^{53}$ But because the destruction of the other ethnic group's culture and identity is as important in ethnic wars as gains of land, targeting violence on women can form an important strategy of war also because of women's central role in culture and family structures. ${ }^{54}$ Wars with ethnic roots are also likely to affect more people on both sides as the appeal to ethnic kinship facilitates mobilization of one's own group and hatred for the other. In addition, they are also likely to last longer and are more difficult to end. Some studies find that civil wars with ethnic roots last much longer than other types of civil wars. ${ }^{55}$ Our sample contains fourteen ethnic conflicts and four nonethnic conflicts with a duration of over ten years, with most long-lasting nonethnic civil wars taking place in Central American countries.

\section{Hypotheses}

Social phenomena such as civil wars can hardly be explained by deterministic theories. Our discussion of the link between militarized conflict and the gender gap in life expectancy is no exception to the rule. Yet the preceding discussion has identified three effects that make a negative influence of militarized conflict on the gender gap in life expectancy probable. In particular, we have explained how and why the economic consequences of war, the displacement effect and the sexual violence effect are likely to jointly affect women more adversely than men. Taking the probabilistic nature of our theory into consideration, we derive the following testable hypotheses from the above discussion:

51. Seifert 1994, 58.

52. Liz Kelly, cited in Shoemaker 2001, 8.

53. Shoemaker 2001 .

54. Seifert 1994.

55. See Fearon 2004; and DeRouen and Sobek 2004. 
H1: Armed conflict is likely to decrease the gender gap in life expectancy.

H2: Armed conflict is likely to decrease the gender gap more strongly if the conflict has ethnic origins.

H3: Armed conflict is likely to decrease the gender gap more strongly if conflict takes place in a country in which the central political order has collapsed.

The following section puts these hypotheses to empirical test.

\section{Research Design}

In the last section we argued that while most direct victims are men, women are likely to suffer more from the indirect adverse consequences of international and civil wars. We measure these adverse consequences by life expectancy. But life expectancy and the gender gap are a product of multiple influences - geographical, social, economical, and political - that one would need to control for to test our hypotheses. Not all determinants of life expectancy are easy to measure. Geographical influences such as the likelihood of acquiring malaria are not equal across countries. A simple cross-sectional analysis of life expectancy is likely to suffer from omitted variable bias, or, if we were to collect data on the national propensities of serious diseases, would suffer from potentially severe measurement errors. To deal with the various estimation problems, we have opted for gathering internationally comparable panel data of life expectancy. The main advantage of relying on panel data is that only pooled data allows controlling for unobserved factors that vary across countries and are possibly correlated with our explanatory variables. Fixed effects estimators eliminate bias from omitted time-invariant variables and also remove the level effects of time-varying omitted variables. Unfortunately and inevitably, the dynamic effects of omitted time-varying variables may still bias the estimates.

To our knowledge, the most reliable source for life expectancy data in panel form is provided by the U.S. Census's International Data Base (IDB). In comparison, for example, to data provided by the World Bank, ${ }^{56}$ the IDP is much better maintained and has by far less missing data. The IDP was created for scientific purposes-in response to the information requirements of International Program Center (IPC) staff to meet the needs of organizations that sponsor research efforts. The IDB combines data from country sources (especially censuses and surveys) 
with IPC's estimates and projections, which are based on available census data and group cohort population projection techniques to compute data between the censuses. These projections are based on country-specific fixed-slope logistic interpolations in the years between national censuses. Moreover, recent population and socioeconomic trends are taken into account "if the projected trends are plausible." ${ }^{57}$ For instance, the projection of fertility takes into account trends in age at marriage, the percentage of women using contraception, and existence and scope of family-planning programs; and data on educational attainment are used in life expectancy calculations.

We nevertheless should expect that analyses of IDB data to some extent suffer from correlated errors, because models that are used to predict the values of a certain variable cannot avoid systematic error. Our analyses inherit these systematic errors. To avoid seriously biased estimates, we use a lagged dependent variable approach, which sufficiently eliminates serially correlated errors. As explained in the literature review, the new WHO data on DALYs lost represent a comprehensive and data-intensive measure and with less measurement errors than a life expectancy measure, but the disadvantage is that DALYs are not yet available over a longer period of time, allowing only a cross-sectional analysis. A cross-sectional analysis does not allow controlling for time-invariant country-specific omitted variables. For these reasons, we prefer data that allows more advanced estimation techniques over cross-sectional data with less measurement errors. Also, while nonadjusted life expectancy is theoretically inferior to disability adjusted life expectancy, we note that the WHO itself has pointed out that the two are highly correlated ${ }^{58}$ In conclusion, in the absence of panel data on adjusted life expectancy, we believe that nonadjusted life expectancy is the single most relevant aggregate measure of public health, which has the important advantage of relatively good over-time and across-country data availability.

The IDB data base provides information on life expectancy for 145 countries and for the years between 1975 and 2002. However, the panel is not balanced, that is, the amount of information available for each country may vary. Next, we will first briefly introduce the data. Then we discuss the estimation problems and the remedies in greater detail. The following sections present the results of our analyses.

\section{Variables and Data Sources}

We use data from various sources. As we explained before, the dependent variable, gender differences in life expectancy, comes from the U.S. Census's IDP data base. Life expectancy varies greatly in the sample we analyze. The mean life expectancy across countries is slightly above sixty-one years, but varies between

57. U.S. Census 2004, B5.

58. Mathers et al. 2001, fig. 4 . 
thirty-seven years in Angola and eighty years in Japan. Over time, average life expectancy has increased from approximately fifty years in 1970 to sixty-five years in 2002.

We use as our dependent variable the ratio rather than the absolute difference of female to male life expectancy. The reason is that, under certain conditions, ${ }^{59}$ changes in the absolute difference of female to male life expectancy can be a misleading indicator of the health effects of events. Therefore, if we measured the gender gap as the absolute difference between the life expectancies of men and women, it is possible that even though an equal number of men and women die, the gender gap is still decreasing. This, in turn, implies that it is possible that male and female life expectancy can decrease by the same number of years and yet more men had died than women. Furthermore, equal proportional decreases in male and female life expectancy will lead to a larger absolute fall in the life expectancy of the gender with the higher ex ante life expectancy-typically the female life expectancy. This problem is accounted for if we measure the gender gap as the ratio of female to male life expectancy. To be on the safe side, we additionally add the absolute change in population life expectancy as a regressor. In simulations, we found that using the life expectancy ratio and controlling for the absolute changes in population life expectancy removes the distortions that result from the computation of life expectancies. ${ }^{60}$

Figure 1 displays the distribution of the ratio of female to male life expectancy across countries.

In 100 out of 2,956 country-years, men lived longer than women (hence the ratio of life expectancies in percent is smaller than 100). In Bangladesh, India, and Nepal, this phenomenon is common and can possibly be attributed to the traditional cultural bias against females in these countries. In all other cases a "negative gender gap" - that is, men living longer than women-is the exception rather than the rule. The highest men-women incline (in our sample) was reported from Sudan in 1988. This was also the time when the civil war in the south had caused a large refugee movement to the cities, especially to Khartoum. In September 1988 the WHO estimated the total number of refugees as up to 750,000 , among which a large portion suffered from severe undernutrition. ${ }^{61}$ On the other end of the spec-

59. Changes in mortality rates of a specific age cohort affect also person-years lived of older age cohorts due to changes to the number of survivors to older age, and this has a larger effect on life expectancy at birth if the life expectancy of the age cohort is higher. See Preston, Heuveline, and Guillot 2001, 64. Militarized conflicts lead to relatively larger changes in the gender gap in life expectancy if the persons killed have not yet reached age cohorts that show large gender differences in mortality rates. For example, if most individuals killed in a war are below thirty years old, and if women above thirty are less likely to die at a certain age than men of the same age and women's life expectancy at birth is higher, then the change in the absolute difference between female and male life expectancy is a biased proxy for the mortality rates of that conflict.

60. For technical details on life expectancy computation, see (http://mathworld.wolfram,com/ LifeExpectancy.html). Accessed 28 April 2006.

61. Toole and Waldman 1988. 


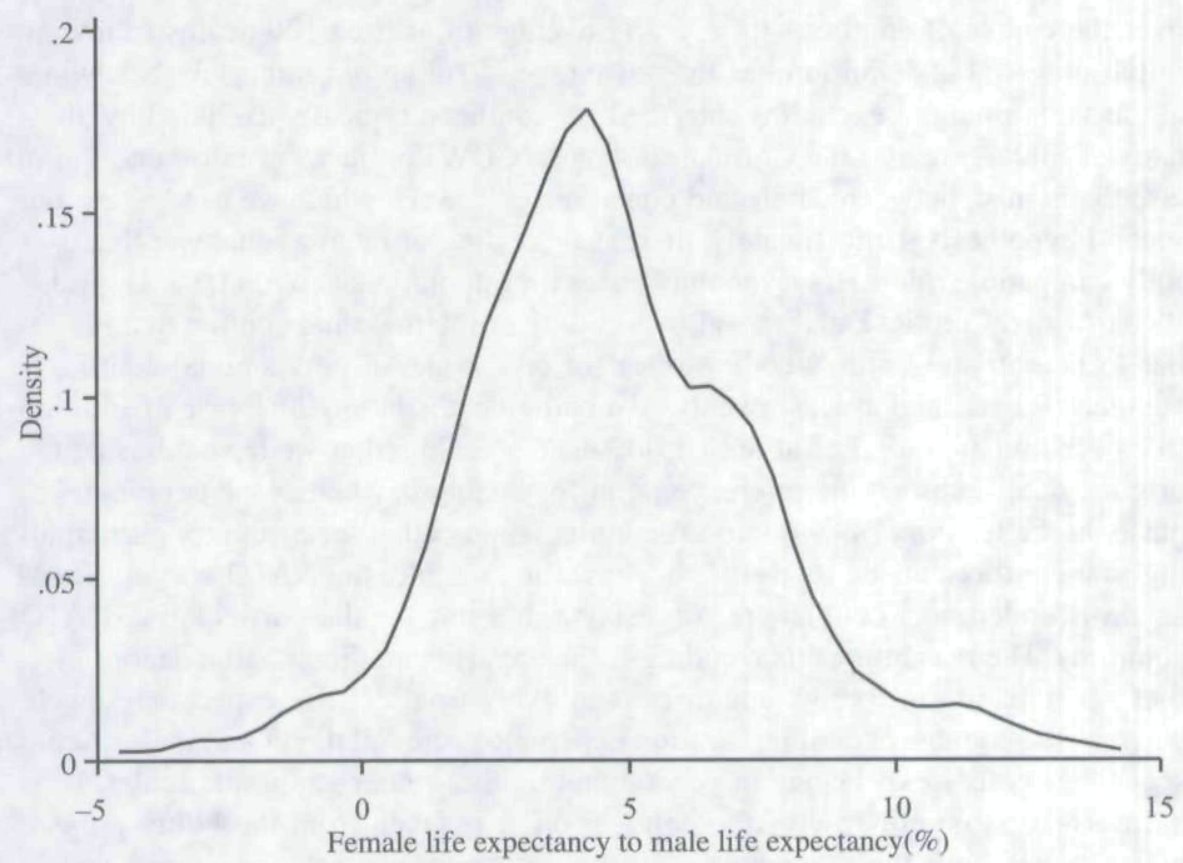

FIGURE 1. Kernel density distribution of the GENDER GAP IN LIFE EXPECTANCY

trum, the absolute difference in female to male life expectancy is largest in posttransition Russia. The life expectancy difference between Russian women and men peaked in 1994 reaching an extraordinary 13.74 years. Reasons were manifold. ${ }^{62}$ Noteworthy, countries from the former Soviet Republic hold forty-eight of the top fifty country-years in terms of gender gap. In all cases, women lived about seventy to seventy-five years while men on average died at the age of sixty or before. If we consider the ratio of female to male life expectancy, then posttransition Russia also has some of the highest values, but Cambodia tops the list. Due to Pol Pot's killing fields, during the years 1975 to 1978 the life expectancies of both genders become extremely low, but female life expectancy is almost 50 percent higher than male life expectancy.

As our measures of civil war, we rely on Fearon and Laitin's coding of civil wars. ${ }^{63}$ Fearon and Laitin count an armed conflict between a state and an organized, nonstate group as a civil war if the conflict leads to at least 1,000 battle deaths

62. While Andreev et al. 2003 hold the Russian health care system responsible, other sources report a steep increase in alcohol abuse and deaths from organized crime; see McKee 1999.

63. Fearon and Laitin 2003. We updated their data from 1999 up to 2002. 
over the course of conflict with a yearly average of at least 100 deaths following initial onset. This definition has the advantage of ruling out minor clashes, while at the same time not excluding intermediate conflicts, typically excluded by alternative sources, such as the Correlates of War (COW) project. ${ }^{64}$ Fearon and Laitin also distinguish between ethnic and nonethnic civil wars, which we need to test our second hypothesis. Unfortunately, there is no coding of international war that uses fully compatible rules. However, our source for international conflict, the Uppsala/ PRIO Armed Conflict Database, allows coding of international conflict that is similar to Fearon and Laitin's coding rules for civil war. An international conflict is counted if it reached at least twenty-five battle deaths in any one year in addition to an accumulated total of at least 1,000 deaths. ${ }^{65}$ Note that we have adjusted the original data such that the reference point for coding is whether the conflict takes place on the territory of a country. A conflict is not coded for a country participating in a conflict outside its territory. Thus, for example, the NATO war on Yugoslavia is coded as a conflict for Yugoslavia, but not for the participating NATO countries. The reason for this recoding is that, apart from direct battle deaths, conflict participation in foreign countries is unlikely to affect life expectancy much, whereas the country of conflict location experiences the full direct and indirect consequences on life expectancy in general and on the gender gap in particular.

Information on collapse of the political order is taken from the Polity project, which codes both the democracy and the autocracy score " -77 " when coders observed "a complete collapse of central political authority." 66 To capture socioeconomic differences across countries we include gross domestic product (GDP) per capita, literacy, and the female labor force participation rate. ${ }^{67}$ These three variables are supposed to catch the effects of three different dimensions, each of which being directly related to individual well-being: income, education, and gender equality. We further include the autocracy score and durability of political regimes, both from the Polity data base in the list of regressors. ${ }^{68}$ Regime durability is defined as the number of years since the most recent three-point change on the polity score or the end of transition from a period of lack of stable political institutions. Other socioeconomic variables, such as health expenditures, access to food, safe water and clean sanitation, income inequality, and the degree of economic freedom typically have poor data availability if they are measurable at all and are highly correlated with the variables we explicitly control for or with the country-specific fixed effects.

64. See 〈http://www.correlatesofwar.org/〉. Accessed 15 March 2006.

65. Strand, Wilhelmsen, and Gleditsch 2004. Recently, there have been attempts to develop cardinal estimates of battle deaths - see, for example, Doyle and Sambanis 2000; and Lacina and Gleditsch 2005. The validity and reliability of these estimates are currently still unclear and we leave using these cardinal measures for future research.

66. See (www.cidcm.umd.edu/inscr/polity). Accessed 15 March 2006.

67. Data from World Bank 2004.

68. See (www.cidcm.umd.edu/inscr/polity/). Accessed 15 March 2006. 
Finally, we add a series of dummy variables that-though imperfectly-seek to catch the effects of natural disasters (earthquake, storms, tsunamis, and so on) and epidemics (HIV/AIDS) on life expectancy. In both cases, we use crude proxies that aim at reducing errors rather than capturing the variance across countries. For natural disasters, we use data from the Emergency Disasters Data Base (EMDAT) ${ }^{69}$ We code the variable 1 if the number of victims of a disaster reported by EM-DAT exceeds 10,000. Along similar lines, we code the HIV/AIDS variable 1 if the share of people living with HIV/AIDS to total population aged fifteen to forty-five exceeds 10 percent, a level at which it is said to have become epidemic. ${ }^{70}$ Appendix 1 provides summary descriptive variable information.

This list of regressors is perhaps incomplete. One should keep in mind, however, that we control for correlation with fixed effects of all variables with sufficient within variation. Of course, there can always exist an omitted time-varying variable whose within variance is highly correlated with the within variance of one of these regressors. We cannot rule out the possibility that such a variable exists, but we are not aware of one.

\section{Estimation Procedure}

Mirroring our theoretical expectations, we are particularly interested in unconditional and conditional effects of armed conflict on the gender gap in life expectancy over the entire conflict period. In principle, it would be useful to distinguish between immediate and lagged effects of conflict. Unfortunately, this is rendered difficult given that conflict data is only discrete and most conflicts last longer than one year. We observe an average conflict duration of 2.77 years for international wars, 7.53 years for nonethnic civil wars, and 11.71 years for ethnic civil wars in our sample. In seven countries-Colombia, Chad, Ethiopia, Sudan, India, the Philippines, and Indonesia-the civil war spans over the entire observation period. A lagged conflict variable would therefore be highly collinear with the contemporaneous conflict variable, which then results in inefficient estimation. Estimation of dummy variables within a lagged dependent variable (LDV) model is even more problematic, because the lagged dependent variable reduces the efficiency of the estimation already. Further adding the lagged values of a dummy regressor would only lead to unreliable estimates.

The fact that armed conflicts and especially civil wars often have a long duration has some advantages as well, however. This is because our coefficients estimate the effects of conflict on life expectancy over the entire conflict periods and thus cover some of the long-term effects of conflict. Life expectancy data is more problematic for estimating short-term effects of conflict because census data for single years of intense conflict often does not exist and the influence of unexpected

69. See (www.em-dat.net). Accessed 15 March 2006.

70. Data from UNDP 2004. 
shocks on life expectancy is notoriously hard to estimate and therefore tends to be unreliable. Specifically, we found life expectancy data in the years of genocides hardly consistent with reported evidence. For example, while Verwimp reports household-level data that suggests that men were more likely to be killed during the genocide in Rwanda than women, ${ }^{71}$ the U.S. census's life expectancy data reports a small decline in the gender gap: while life expectancy of men declined from 45.1 to 41.1 years between 1993 and 1995, female life expectancy declined by 4.8 years from 47.2 to 42.4 years over the same period (implying that the ratio of female to male life expectancy decreased from 104.6 to 103.2 percent during those years). ${ }^{72}$ However, life expectancy data allows more precise estimates of the total effects of armed conflict over the entire conflict period, because it captures not only the direct but also the indirect casualties of war. Often these indirect casualties of armed conflict find little attention in the media and in academic research. Life expectancy data may help to unveil these long-term effects.

Basically, the estimation procedure we employ compares average change in the gender gap in life expectancy in conflict countries with the average change in the gender gap in nonconflict countries. However, the interpretation of our estimation coefficients is slightly more complex. To capture the explainable level differences between countries we add the lagged dependent variable to the right-hand-side variables. With a coefficient of approximately 0.9 , our dependent variable is "quasidifferenced"- as econometricians dubbed it.

An unbiased and efficient estimation has to resolve a series of econometric complications. We discuss the most important problems in turn. To start with, panel data analyses are typically hampered by the notorious problem of serially correlated errors. Unfortunately, serial correlation may have many sources. A wrongly specified model, false assumptions about lagged effects of explanatory variables, persistent effects, and related problems all may lead to autocorrelation. Broadly speaking, the literature provides two ways to deal with autocorrelation. The first approach seeks to exactly model the dynamics of all variables and has clear advantages in time-series analyses. In panel data, however, it is likely that unit-specific dynamics exist. In this case, the first approach would lead to estimates that at best capture the average dynamics over all units. Therefore, most dynamic analyses of panel data have relied on the second approach and treated autocorrelation as nuisance. Researchers aim at estimating unbiased coefficients without carefully modeling the dynamics of the explanatory variables. The LDV approach, on which we rely, is the most prominent example of the second group.

In addition, a fixed-effects model is required if omitted variables or initial variance exists that are correlated with at least one explanatory variable. However,

71. Verwimp 2003.

72. Men were possibly the main target in other historical events of large-scale genocides as well, even though this is contested-see the contributions in Jones 2004. In sensitivity analysis we found that it makes little difference to our estimates if we drop observations from years of and surrounding events of genocide from the data based on information contained in Harff 2003. 
scholars have frequently argued that fixed effects models may "throw the baby out with the bathwater" because they completely abandon the between variance. ${ }^{73}$ The estimation of rarely changing variables becomes highly inefficient-so inefficient that point estimates can be extremely biased. This is important because militarized conflict must be classified as a rarely changing variable. Specifically, conflict is extremely rare with a within variance between 0.009 (international war) and 0.054 (civil war). Estimation of the impact of conflict on life expectancy by a fixedeffects model can lead to coefficients far off the true coefficients. Moreover, natural disasters of a given magnitude are even less frequent. In all these cases, we cannot expect to obtain unbiased point estimates using a fixed effects approach.

Hsiao and Plümper and Troeger have suggested a remedy for this type of estimation problem. ${ }^{74}$ Plümper and Troeger-in brief-propose using a three-stage estimator to obtain unbiased estimates of variables that have enough within variance to allow efficient estimation while at the same time estimating rarely changing variables by pooled ordinary least squares (OLS). This technique thus trades unbiasedness for efficiency, which in finite samples pays off with more reliable point estimates if the within variance is really low. Efficient estimation is especially important if the regressor of interest is an event dummy as in our case. De-meaning these event dummies leads to extremely inefficient estimation. Units that show no within-variation over time either because they never experienced a militarized conflict or because a conflict stretched over the entire period that we analyze would not contribute to the estimation of the militarized conflict coefficients. ${ }^{75}$ As a result, the point estimates would be hardly reliable. We thus estimate the conflict variables (as well as the natural disaster and the HIV/AIDS variables that have similar characteristics) using both within and between variance while at the same time controlling for potential correlation with country fixed effects for the remaining variables that have enough within variation over time.

\section{Analysis}

\section{Mean Sample Effects}

Table 1 presents our estimation results. ${ }^{76}$ We report results from two models: A full sample model and a model that excludes countries where HIV/AIDS has

73. Beck and Katz 2001.

74. See Hsiao 2003; 51-53; and Plümper and Troeger 2004 and 2005.

75. See Plümper, Troeger, and Manow 2005.

76. We have tested whether our dependent variable has a unit root. Because we analyze an unbalanced panel, the standard Im, Pesaran, and Shin 2003 test, the most reliable unit root test for panel data, is not applicable. Instead, we regressed the gender gap on its lagged value in an otherwise empty fixed effects model. We then use an F-test to test whether the estimated coefficient equals 1 . This is 68.81 in the full sample and 131.77 in the sample where the high HIV prevalence countries are excluded, significantly rejecting the null. We thus do not consider the possibility of a unit root further. 
TABLE 1. Determinants of the dependent variable GENDER GAP IN LIFE EXPECTANCY

\begin{tabular}{|c|c|c|}
\hline $\begin{array}{l}\text { Dependent variable: } \\
\text { Ratio of female to male life expectancy } * 100\end{array}$ & $\begin{array}{c}\text { Model } 1 \\
\text { (full sample) }\end{array}$ & $\begin{array}{c}\text { Model } 2 \\
\text { (HIV epidemic } \\
\text { country-years } \\
\text { excluded })\end{array}$ \\
\hline LAGGED GENDER GAP & $\begin{array}{l}0.8899 \\
(0.0088)^{* * *}\end{array}$ & $\begin{array}{l}0.8370 \\
(0.0112)^{* * * *}\end{array}$ \\
\hline CHANGE IN POPULATION LIFE EXPECTANCY & $\begin{array}{l}0.0604 \\
(0.0158)^{* * *}\end{array}$ & $\begin{array}{l}0.0656 \\
(0.0169) * * *\end{array}$ \\
\hline INTERSTATE CONFLICT & $\begin{array}{l}-0.3835 \\
(0.2047)^{*}\end{array}$ & $\begin{array}{l}-0.4293 \\
(0.2016)^{*}\end{array}$ \\
\hline CIVIL WAR & $\begin{array}{l}-0.3471 \\
(0.0621)^{* * * *}\end{array}$ & $\begin{array}{l}-0.3212 \\
(0.0613) * * *\end{array}$ \\
\hline INCOME PER CAPITA & $\begin{array}{c}0.0000 \\
(0.0000)\end{array}$ & $\begin{array}{c}0.0000 \\
(0.0000)\end{array}$ \\
\hline AUTOCRATIC INSTITUTIONS & $\begin{array}{l}0.0260 \\
(0.0077) * * *\end{array}$ & $\begin{array}{l}0.0363 \\
(0.0082)^{* * * *}\end{array}$ \\
\hline REGIME DURABILITY & $\begin{array}{l}-0.0042 \\
(0.0016) * *\end{array}$ & $\begin{array}{l}-0.0014 \\
(0.0017)\end{array}$ \\
\hline LITERACY RATE & $\begin{array}{l}-0.0250 \\
(0.0025)^{* * *}\end{array}$ & $\begin{array}{l}-0.0181 \\
(0.0021)^{* * *}\end{array}$ \\
\hline FEMALE LABOR FORCE PARTICIPATION & $\begin{array}{l}0.0428 \\
(0.0043)^{* * * * * *}\end{array}$ & $\begin{array}{l}0.0425 \\
(0.0041)^{* * *}\end{array}$ \\
\hline NATURAL DISASTERS & $\begin{array}{l}-1.5821 \\
(0.3302) * * *\end{array}$ & $\begin{array}{l}-1.7831 \\
(0.3432)^{* * *}\end{array}$ \\
\hline HIVIAIDS $>10 \%$ OF POPULATION $15-45$ & $\begin{array}{l}-0.7437 \\
(0.0854) * * *\end{array}$ & .. \\
\hline Intercept & $\begin{array}{l}12.0858 \\
(0.9489)^{* * *}\end{array}$ & $\begin{array}{l}17.1981 \\
(1.1842) * * *\end{array}$ \\
\hline Observations & 1836 & 1647 \\
\hline Countries & 106 & 96 \\
\hline$F$-test & $3606.75^{* 14}$ & $3580.32 * * * *$ \\
\hline$t(e t a)$ & $0.0791^{* * * *}$ & $0.0736^{* * * *}$ \\
\hline Adjusted $R^{2}$ & 0.959 & 0.960 \\
\hline
\end{tabular}

Note: Standard errors are in parentheses. ${ }^{*} p<0.05 ;{ }^{* *} p<0.01 ;{ }^{* * *} p<0.001$.

become epidemic (prevalence rates over 10 percent). We will see that the results are largely robust. Table 1 shows that both international and civil conflicts tend to gradually close the gender gap in life expectancy. Based on Model 1, an interstate war reduces the ratio of female to male life expectancy by 0.38 percentage points, a civil war reduces this ratio by 0.34 percentage points. Perhaps surprisingly, wars between two countries have a larger average effect on the gender gap than civil wars. Further below, we will see that there are important differences among civil wars not yet accounted for. In the restricted sample, the coefficients for interstate and internal conflict remain statistically significant. The significant coefficient of the eta, which is the unexplained part of the unit fixed effects, suggests that the estimation still has to account for omitted time-invariant variables. 
Before we explore the relations between the various conflict types and the gender gap in life expectancy further, we briefly discuss the estimated effects of the control variables. We find that while a higher per capita income boosts life expectancy, it does not seem to make a difference to the life expectancy gap between men and women. The gender gap significantly widens in autocratic regimes. Political stability has no effect in the restricted sample, but decreases the gender gap in the full sample. We are not surprised to find that female labor force participation actually widens the gender gap. Of course, women's predisposition for heart attacks and lung cancer is likely to increase with higher labor force participation, ${ }^{77}$ but even if this is the case, the beneficial effects of a more self-determined life seem to outweigh the disadvantages of workplace stress. Events of natural disasters have a qualitatively similar effect to armed conflict, also closing the gender gap. ${ }^{78}$ Countries with a high HIV/AIDS prevalence rate have a lower gender gap in life expectancy, all other things equal. It appears that young women in sub-Saharan Africa, the region with the highest prevalence rates, are more likely to become infected than men. ${ }^{79}$ As a consequence, HIV/AIDS has a greater impact on women than men in developing countries relative to other causes of disease and disability. ${ }^{80}$

\section{Conditional Effects}

Not all militarized conflicts are alike - to say the least. Some wars are more violent, some occur in politically unstable countries, some conflicts are ethnically motivated, and so on. Of course, one could say this variance in the severity of militarized conflicts renders the estimation of mean effects such as those presented in the previous section meaningless. But that is not true: knowing that on average women are more affected over the entire conflict period is already interesting.

In the theoretical section, we have argued that the influence of militarized conflict on the gender gap is likely to be influenced by whether the conflict has ethnic roots and the political authority in the country has collapsed. In this section we test these conjectures by estimating individual coefficients for ethnic and nonethnic civil conflicts as well as for these conflict types in countries where the central political authority has collapsed and where it has not (in our sample, no failed states engaged in international conflict). Table 2 reports the results. It allows an easy robustness check because we repeat results from Model 1 again in the first column.

Observe that our estimates do not vary much following the inclusion of variables that capture conditionality. Most coefficients of the conditional Model 3 do

77. Pampel 2003.

78. We intend to explore the effect of natural disasters on the gender gap in life expectancy in more detail in future research.

79. UN 2002, 20.

80. ICRC 2001, 112. 
TABLE 2. Conditional estimation results (full sample)

\begin{tabular}{|c|c|c|c|}
\hline $\begin{array}{l}\text { Dependent variable: } \\
\text { ratio of female to male life expectancy } * 100\end{array}$ & Model 1 & Model 3 & Model 4 \\
\hline LAGGED GENDER GAP & $\begin{array}{l}0.8899 \\
(0.0088)^{\text {*k*k }}\end{array}$ & $\begin{array}{l}0.8895 \\
(0.0088)^{* * *}\end{array}$ & $\begin{array}{l}0.8866 \\
(0.0089)^{* * * *}\end{array}$ \\
\hline CHANGE IN POPULATION LIFE EXPECTANCY & $\begin{array}{l}0.0604 \\
(0.0158)^{* * *}\end{array}$ & $\begin{array}{l}0.0609 \\
(0.0158)^{* * * *}\end{array}$ & $\begin{array}{l}0.0613 \\
(0.0158)^{* * * * *}\end{array}$ \\
\hline INTERSTATE CONFLICT & $\begin{array}{l}-0.3835 \\
(0.2047)^{*}\end{array}$ & $\begin{array}{l}-0.3388 \\
(0.2050)^{*}\end{array}$ & $\begin{array}{l}-0.3746 \\
(0.2053)^{*}\end{array}$ \\
\hline CIVIL WAR & $\begin{array}{l}-0.3471 \\
(0.0621)^{* * *}\end{array}$ & & \\
\hline NONETHNIC CIVIL WAR & & $\begin{array}{r}-0.0486 \\
(0.1209)\end{array}$ & \\
\hline ETHNIC CIVIL WAR & & $\begin{array}{l}-0.4122 \\
(0.0677)^{* * *}\end{array}$ & \\
\hline NONETHNIC CIVIL WAR W/O STATE FAILURE & & & $\begin{array}{r}-0.0616 \\
(0.1215)\end{array}$ \\
\hline NONETHNIC CIVIL WAR IN FAILED STATES & & & $\begin{array}{c}1.0301 \\
(0.9711)\end{array}$ \\
\hline ETHNIC CIVIL WAR W/O STATE FAILURE & & & $\begin{array}{l}-0.4074 \\
(0.0677)^{\text {**** }}\end{array}$ \\
\hline ETHNIC CIVIL WAR IN FAILED STATES & & & $\begin{array}{l}-0.7925 \\
(0.3258)^{*}\end{array}$ \\
\hline INCOME PER CAPITA & $\begin{array}{c}0.0000 \\
(0.0000)\end{array}$ & $\begin{array}{c}0.0000 \\
(0.0000)\end{array}$ & $\begin{array}{c}-0.0000 \\
(0.0000)\end{array}$ \\
\hline AUTOCRATIC INSTITUTIONS & $\begin{array}{l}0.0260 \\
(0.0077)^{* * *}\end{array}$ & $\begin{array}{l}0.0256 \\
(0.0077)^{* * *}\end{array}$ & $\begin{array}{l}0.0225 \\
(0.0076)^{* * *}\end{array}$ \\
\hline REGIME DURABILITY & $\begin{array}{l}-0.0042 \\
(0.0016)^{* *}\end{array}$ & $\begin{array}{l}-0.0039 \\
(0.0017)^{*}\end{array}$ & $\begin{array}{l}-0.0030 \\
(0.0016)^{*}\end{array}$ \\
\hline LITERACY RATE & $\begin{array}{l}-0.0250 \\
(0.0025)^{* * *}\end{array}$ & $\begin{array}{l}-0.0251 \\
(0.0025)^{* * *}\end{array}$ & $\begin{array}{l}-0.0252 \\
(0.0025) * * *\end{array}$ \\
\hline FEMALE LABOR FORCE PARTICIPATION & $\begin{array}{l}0.0428 \\
(0.0043)^{* * * *}\end{array}$ & $\begin{array}{l}0.0431 \\
(0.0043)^{* * *}\end{array}$ & $\begin{array}{l}0.0429 \\
(0.0043)^{* *}\end{array}$ \\
\hline NATURAL DISASTERS & $\begin{array}{l}-1.5821 \\
(0.3302) * * *\end{array}$ & $\begin{array}{l}-1.5333 \\
(0.3306)^{* * *}\end{array}$ & $\begin{array}{l}-1.5508 \\
(0.3305)^{* * *}\end{array}$ \\
\hline HIV/AIDS $>10 \%$ OF POPULATION $15-45$ & $\begin{array}{l}-0.7437 \\
(0.0854)^{* * *}\end{array}$ & $\begin{array}{l}-0.7352 \\
(0.0852)^{* * * *}\end{array}$ & $\begin{array}{l}-0.7361 \\
(0.0851)^{* * *}\end{array}$ \\
\hline Intercept & $\begin{array}{l}12.0858 \\
(0.9489)^{* * *}\end{array}$ & $\begin{array}{l}12.1190 \\
(0.9530)^{* * *}\end{array}$ & $\begin{array}{l}12.4568 \\
(0.9678) * * *\end{array}$ \\
\hline Observations & 1836 & 1836 & 1836 \\
\hline Countries & 106 & 106 & 106 \\
\hline F-test & $3606.75^{* * *}$ & $3328.32 * * *$ & $2890.55^{* * *}$ \\
\hline$t($ eta $)$ & $0.0791^{* * *}$ & $0.0792 * * *$ & $0.0782 * * *$ \\
\hline Adjusted $R^{2}$ & 0.959 & 0.959 & 0.959 \\
\hline
\end{tabular}

Note: Standard errors are in parentheses. ${ }^{*} p<0.05 ;{ }^{* *} p<0.01 ;{ }^{* * *} p<0.001$.

not deviate significantly from the coefficients of the unconditional Model 1 . When we distinguish between ethnic and nonethnic civil wars, we find that it is only ethnic civil wars that reduce the gender gap in life expectancy. Of course, one has to keep in mind that the vast majority of civil wars has ethnic roots. When we 
further distinguish between ethnic and nonethnic civil wars taking place in "failed" states and "nonfailed" states (Model 4), then we find that it is ethnic wars in failed states that have the largest impact on the gender gap in life expectancy, reducing the female to male life expectancy ratio by 0.79 percentage points, whereas the effect of ethnic civil wars in other countries is 0.40 percentage points. ${ }^{81}$ In both conditional models, the effect of interstate conflict remains statistically significant, with an estimated magnitude of between 0.34 and 0.38 percentage points.

To sum up, we found support for our first hypothesis that over the entire conflict period, the gender gap in life expectancy decreases. Our second and third hypotheses, namely, that this decline is stronger when the conflict has ethnic origins or the political order collapses, needs to be qualified, however: ethnic civil wars have an effect that is stronger still in failed states, whereas nonethnic civil wars do not have any effect. This finding does not necessarily falsify our second and third hypotheses in respect to nonethnic civil wars. Rather, ethnic civil wars are more common than nonethnic civil wars and ethnic civil wars are more likely than nonethnic civil wars to take place in failed states. Therefore, the conditional estimates for nonethnic civil wars suffer largely from inefficiency. Better state failure data and more wars may help to improve estimates, but the world would be much better off if we had to wait a long time before the conditions for efficient estimation were satisfied.

\section{Conclusion}

Militarized conflicts kill in various ways. They kill soldiers and civilians directly, but also have important indirect effects and find their victims among the larger civilian population, killing people that have never crossed the line of fire. We have argued that women are likely to suffer more from these negative indirect effects and possibly to an extent that overall they could be more adversely affected by conflict than men, despite the fact that men naturally are the main direct victims of war. We have demonstrated that, indeed, on average women suffer more than men from international and civil wars, as measured by the effect of conflict on the ratio of female to male life expectancy. This confirms our first hypothesis. The average decline in the gender gap in life expectancy suggests that the direct and indirect consequences of wars combined either kill more women or that the killed women are younger on average than the killed men. Findings on our second and third hypotheses have been more mixed, however. We have found that the effect on the gender gap is indeed stronger if the civil war has ethnic roots, which con-

81. To illustrate, assume that life expectancy in a country is 60.0 years for men and 64.8 years for women (implying a score of 108 on our dependent variable). If an ethnic war in a failed state reduced men's life expectancy by 2 years to 58.0 years, women's life expectancy would decline by 2.62 years to 62.18 years. 
firms our second hypothesis. But the type of civil war matters even more than we expected because we find that only ethnic civil wars decrease the gender gap, whereas nonethnic civil wars do not. Similarly, we find that it is only for ethnic civil wars that the effect on the gender gap becomes stronger if the conflict takes place in a "failed" state, in accordance with our third hypothesis, but not for nonethnic civil wars. As we explained above, the caveat is that few civil wars are nonethnic and even fewer civil wars in "failed" states are nonethnic, such that variation is low and estimation inefficient.

The finding that, on average, conflicts lower the life expectancy of women more than that of men means that policymakers, nongovernmental organizations, and the academic community need to pay much closer attention to the hidden, indirect consequences of conflict, which are both "profound" and "underappreciated." 82 The three recent studies from UN bodies and the International Committee of the Red Cross mentioned in the introduction represent a first start. Our findings challenge policymakers and international and humanitarian organizations to develop policies that mitigate and ideally prevent the adverse impact of armed conflict on women. Such policies have to address the specific vulnerabilities of women that follow from severe damage to the health and other infrastructure that result when a large part of the population has been displaced from their homes and when sexual violence against women forms part of the military strategy employed. While the priority given to women in emergency evacuations during episodes of armed conflict might be misguided given the specific vulnerability of noncombatant men during ongoing conflicts, ${ }^{83}$ this does not imply that giving priority to women is generally misguided. Instead, our findings suggest giving priority to women when it comes to the indirect and long-term effects of armed conflicts.

Our study opens up important avenues for future research in IR. First, future research could explore characteristics of conflicts other than the ones looked at here, which might help explain why some conflicts apparently are so much more damaging to women, whereas others are not. In the analyses supplementing the estimates we reported here (see Appendix 2), we found some regional differences for international wars, but not for ethnic civil wars (only ethnic civil wars in southern Africa were estimated to be even more damaging to women than the average effect). More in-depth case study research might be able to elicit reasons for these differences. Second, the theoretical justification for our hypotheses can explain our findings, but future research should provide a better understanding and a more detailed account on the relative importance of specific channels through which armed conflict harms women more than men. For example, is damage to the health infrastructure or damage to agricultural and food distribution systems more important? Third, future research should address what role, if any, the effect of armed conflict on the gender gap in life expectancy plays for the likelihood of external

82. Human Security Centre 2004, 18.

83. As demonstrated by Jones 1994, and 2000; and Carpenter 2003. 
policy intervention as well as how external intervention impacts on the effect of armed conflict. Why do multinational peace-keeping forces intervene in some conflicts but not in others? Why do international donors attempt to rebuild the country with the help of enormous sums of development aid and technical assistance after some conflicts but not others? How is international aid related to the politics of the government in crisis countries? Do these interventions have a significant effect on the impact of armed conflict on the gender gap in life expectancy and, if so, under what conditions?

From a methodological point of view, we believe that future research would benefit from a more disaggregated and case-study type of approach. On the one hand, studies are needed that analyze the individual level. For instance, political scientists and economists should have a better understanding of how government failure and ethnic conflicts affect the prices of goods of basic need. As yet, we have a much better understanding on how markets work in good times, but we know relatively little about the operation of markets in the presence of natural or man-made disasters. On the other hand, case studies could provide additional insights into the interdependencies between the various effects of militarized conflict and political institutions. For many of the new research avenues that could be taken from this study's results, the quality of data and the number of observations are likely to be insufficient for macro-level studies to provide interesting results.

\section{Appendix 1. Descriptive Statistics}

\begin{tabular}{|c|c|c|c|c|c|}
\hline Variables & Observations & Mean & $\begin{array}{l}\text { Standard } \\
\text { deviation }\end{array}$ & Minimum & Maximum \\
\hline GENDER GAP & 1836 & 107.31 & 4.80 & 91.07 & 128.30 \\
\hline \multicolumn{6}{|l|}{ CHANGE IN POPULATION } \\
\hline LIFE EXPECTANCY & 1836 & 0.16 & 1.48 & -36.47 & 32.09 \\
\hline PER CAPITA INCOME & 1836 & 4366.94 & 4185.52 & 438.61 & 23408.34 \\
\hline AUTOCRATIC INSTITUTIONS & 1836 & 3.37 & 3.48 & 0.00 & 10.00 \\
\hline REGIME DURABILITY & 1836 & 14.97 & 15.75 & 0.00 & 82.00 \\
\hline LITERACY RATE & 1836 & 70.42 & 23.21 & 11.04 & 99.80 \\
\hline FEMALE LABOR FORCE PARTICIPATION & 1836 & 37.28 & 9.23 & 6.30 & 52.72 \\
\hline NATURAL DISASTERS & 1836 & 0.005 & 0.070 & 0.00 & 1.00 \\
\hline INTERNATIONAL CONFLICT & 1836 & 0.014 & 0.116 & 0.00 & 1.00 \\
\hline CIVIL WAR & 1836 & 0.230 & 0.421 & 0.00 & 1.00 \\
\hline NONETHNIC CIVIL WAR & 1836 & 0.039 & 0.194 & 0.00 & 1.00 \\
\hline ETHNIC CIVIL WAR & 1836 & 0.196 & 0.397 & 0.00 & 1.00 \\
\hline \multicolumn{6}{|l|}{ NONETHNIC CIVIL WAR WITHOUT } \\
\hline STATE FAILURE & 1836 & 0.001 & 0.023 & 0.00 & 1.00 \\
\hline NONETHNIC CIVIL WAR IN FAILED STATES & 1836 & 0.039 & 0.193 & 0.00 & 1.00 \\
\hline ETHNIC CIVIL WAR W/O STATE FAILURE & 1836 & 0.190 & 0.392 & 0.00 & 1.00 \\
\hline ETHNIC CIVIL WAR IN FAILED STATES & 1836 & 0.005 & 0.074 & 0.00 & 1.00 \\
\hline HIV/AIDS $>10 \%$ OF POPULATION $15-45$ & 1836 & 0.103 & 0.304 & 0.00 & 1.00 \\
\hline
\end{tabular}

Note: Based on Models 1, 3, and 4 samples. 
TABLE A1. Jackknife permutation test (groupwise exclusion) based on Model 3

95\% confidence intervals

Excluded group of countries

None

North and Middle America

South America

West and Central Europe

East and South-East Europe

Central Africa

Southern Africa

Northern Africa

Asia

Australia \& Oceania
Ethnical civil war

COW code 500-599 excluded

COW code $600-699$ excluded

COW code 700-850 excluded

COW code $>850$ excluded

Interstate
conflict

Civil war

$\begin{array}{llllll}-0.74 . . & 0.06 & -0.29 . . & 0.19 & -0.54 . . & -0.28 \\ -0.49 . . & 0.23 & -0.28 . . & 0.27 & -0.55 . . & -0.29 \\ -0.70 . . & 0.17 & -0.33 . . & 0.23 & -0.75 . . & -0.41 \\ -0.74 . . & 0.08 & -0.25 \ldots & 0.23 & -0.87 . . & -0.53 \\ -0.60 . . & 0.20 & -0.15 . . & 0.32 & -0.77 . . & -0.43 \\ -1.25 . . & 0.37 & -0.67 . . & -0.16 & -0.86 . . & -0.51 \\ -0.71 . . & 0.74 & -0.24 . . & 0.19 & -0.23 . . & 0.02 \\ -1.28 . . & 0.43 & -0.55 . . & -0.27 & -0.71 . . & -0.41 \\ -0.57 . . & 0.99 & -0.28 . . & 0.28 & -0.81 . . & -0.45 \\ -0.73 . . & 0.08 & -0.29 . . & 0.19 & -0.57 . . & -0.30\end{array}$

Note: COW code refers to country code from the Correlates of War project.

TABLE A2. Results from bootstrap modeling

\begin{tabular}{|c|c|c|c|c|c|}
\hline Variable & Replications & Observed & Bias & $\begin{array}{l}\text { Standard } \\
\text { error }\end{array}$ & $\begin{array}{l}\text { 95\% confidence } \\
\text { interval }\end{array}$ \\
\hline
\end{tabular}

\begin{tabular}{lcccccccc}
\hline \multicolumn{10}{c}{ Model I } \\
\hline INTERSTATE CONFLICT & 1000 & -0.383 & -0.004 & 0.173 & -0.723 & -0.044 & $\mathrm{~N}$ \\
CIVIL. WAR & 1000 & -0.347 & -0.001 & 0.080 & -0.505 & -0.189 & $\mathrm{~B}$ \\
& & & & & -0.507 & -0.191 & $\mathrm{BC}$ \\
\hline
\end{tabular}

Model 3

\begin{tabular}{|c|c|c|c|c|c|c|c|}
\hline INTERNATIONAL. WAR & 1000 & -0.339 & 0.007 & 0.185 & $\begin{array}{l}-0.702 \\
-0.671\end{array}$ & $\begin{array}{l}0.025 \\
0.048\end{array}$ & $\underset{B C}{N}$ \\
\hline NONETHNIC CIVIL. WAR & 1000 & -0.049 & 0.001 & 0.178 & $\begin{array}{l}-0.398 \\
-0.350\end{array}$ & $\begin{array}{l}0.300 \\
0.369\end{array}$ & $\begin{array}{l}\mathrm{N} \\
\mathrm{BC}\end{array}$ \\
\hline ETHNIC CIVIL WAR & 1000 & -0.412 & 0.002 & 0.093 & $\begin{array}{l}-0.595 \\
-0.611\end{array}$ & $\begin{array}{l}-0.230 \\
-0.238\end{array}$ & $\begin{array}{l}\mathrm{N} \\
\mathrm{BC}\end{array}$ \\
\hline
\end{tabular}

Note: $\mathrm{N}=$ normal, $\mathrm{BC}=$ bias corrected.

\section{Appendix 2. Robustness Tests}

We did two robustness tests - groupwise jackknife and bootstrap-to study whether the results reported in Model 3 of Table 2 stand up against the apparent variance across conflicts. See Table A1. A groupwise jackknife excludes each group of observation once. In the jackknife, we tested the robustness of our model in respect to such influence by eliminating 
groups of neighboring countries from the estimation. We distinguish between nine country groups: North and Middle America, South America, West and Central Europe, East and South-East Europe, Central Africa, Southern Africa, Northern Africa, Asia, as well as Australia and Ozeania. We found that for civil wars and especially for ethnic civil wars the estimates presented in Table 2 are fairly robust to the exclusion of geographical regions. The effect of interstate wars on the relative gender gap, however, shows strong regional variations, suggesting that not all international wars are alike in their influence on the civil population. The only statistically significant deviation for ethnic civil wars is southern Africa, where such conflicts affect women more strongly still than the average conflict in the global sample as the confidence interval lies entirely above the one from the global sample.

We observe similar robustness when bootstrapping Models 1 and 3. See Table A2. We used various procedures, each with 1,000 replications. We observed that the estimated bias for all variables including the conflict variables is negligibly low (we show only the bootstrapped results of the conflict variables here). The confidence intervals of both the normal regression and the bias corrected results almost perfectly overlap. Thus we may conclude that our results are not sensitive to particular cases.

\section{References}

Andreev, Evgueni, Ellen Nolte, Vladimir Shkolnikov, Elena Varavikova, and Martin McKee. 2003. The Evolving Pattern of Avoidable Mortality in Russia. International Journal of Epidemiology 32 (3):437-46.

Ashford, Mary-Wynne, and Yolanda Huet-Vaughn. 1997. The Impact of War on Women. In War and Public Health, edited by Berry S. Levy and Victor W. Sidel, 186-96. New York: Oxford University Press.

Askin, Kelly Dawn. 1997. War Crimes Against Women-Prosecution in War Crimes Tribunals. The Hague, Netherlands: Martinus Nijhoff.

Beck, Nathaniel, and Jonathan Katz. 2001. Throwing Out the Baby with the Bath Water: A Comment on Green, Kim, and Yoon. International Organization 55 (2):487-95.

Bossuyt, N., S. Gadeyne, P. Deboosere, and H. van Oyen. 2004. Socio-Economic Inequalities in Health Expectancy in Belgium. Public Health 118 (1):3-10.

Caprioli, Mary. 2000. Gendered Conflict. Journal of Peace Research 37 (1):51-68.

2003. Gender Equality and State Aggression: The Impact of Domestic Gender Equality on

State First Use of Force. International Interactions 29 (3):195-214.

2004. Feminist IR Theory and Quantitative Methodology: A Critical Analysis. International Studies Review 6 (2):253-69.

2005. Primed for Violence: The Role of Gender Inequality in Predicting Internal Conflict. International Studies Quarterly 49 (2):161-78.

Caprioli, Mary, and Mark A. Boyer. 2001. Gender, Violence, and International Crisis. Journal of Confict Resolution 45 (4):503-18.

Carpenter, R. Charli. 2002. Gender Theory in World Politics: Contributions of a Nonfeminist Standpoint? International Studies Review 4 (3):153-65.

2003. "Women and Children First": Gender, Norms, and Humanitarian Evacuation in the Balkans 1991-95. International Organization 57 (4):661-94.

2004. Beyond "Genderdice." In Gendercide and Genocide, edited by Adam Jones, 230-56. Nashville, Tenn.: Vanderbilt University Press.

2005. "Women, Children and Other Vulnerable Groups": Gender, Strategic Frames and the Protection of Civilians as a Transnational Issue. International Studies Quarterly 49 (2):295-334. 
Carver, Terrell. 2004. Men and Masculinities in Gendercide/Genocide. In Gendercide and Genocide, edited by Adam Jones, 272-94. Nashville, Tenn.: Vanderbilt University Press.

Collier, Paul. 1999. On the Economic Consequences of Civil War. Oxford Economic Papers 51 (1):168-83.

Davenport, Christian, Will H. Moore, and Steven C. Poe. 2003. Sometimes You Just Have to Leave: Domestic Threats and Forced Migration, 1964-1989. International Interactions 29 (5):27-55.

Davis, David R., and Joel N. Kuritsky. 2002. Violent Conflict and Its Impact on Health Indicators in Sub-Saharan Africa. Working Paper. Atlanta, Ga.: Emory University.

DeRouen, Karl R., Jr., and David Sobek. 2004. The Dynamics of Civil War Duration and Outcome. Journal of Peace Research 41 (3):275-301.

Doyle, Michael W., and Nicholas Sambanis. 2000. International Peacebuilding: A Theoretical and Quantitative Analysis. American Political Science Review 94 (4):779-801.

Drèze, Jean, and Amartya Sen. 1990. Hunger and Public Action. Oxford, England: Clarendon Press.

Food and Agriculture Organization (FAO). 2005. Assessment of the World Food Security Situation. Rome: FAO.

Fearon, James D. 2004. Why Do Some Civil Wars Last so Much Longer Than Others? Journal of Peace Research 41 (3):275-301.

Fearon, James D., and David D. Laitin. 2003. Ethnicity, Insurgency, and Civil War. American Political Science Review 97 (1):75-90.

Foege, William H. 1997. Arms and Public Health: A Global Perspective. In War and Public Health, edited by Berry S. Levy and Victor W. Sidel, 3-11. New York: Oxford University Press.

Garfield, Richard M., and Alfred I. Neugut. 1997. The Human Consequences of War. In War and Public Health, edited by Berry S. Levy and Victor W. Sidel, 27-38. New York: Oxford University Press.

Ghobarah, Hazem Adam, Paul Huth, and Bruce Russett. 2003. Civil Wars Kill and Maim PeopleLong After the Shooting Stops. American Political Science Review 97 (2):189-202.

. 2004. The Postwar Public Health Effects of Civil Conflict. Social Science \& Medicine 59 (2):869-84.

Gyimah-Brempong, Kwabena, and Marva E. Corley. 2005. Civil War Incidence and Economic Growth in Africa, Journal of African Economics 14 (2):270-311.

Harff, Barbara. 2003. No Lessons Learned from the Holocaust? Assessing Risks of Genocide and Political Mass Murder Since 1955. American Political Science Review 97 (1):57-73.

Hertz, Erica, James R. Hebert, and Joan Landon. 1994. Social and Environmental Factors and Life Expectancy, Infant Mortality, and Maternal Mortality Rates: Results of a Cross-National Comparison. Social Science \& Medicine 39 (1):105-44.

Hsiao, Cheng. 2003. Analysis of Panel Data. Cambridge: Cambridge University Press.

Human Security Centre. 2004. Deadly Connections: The War/Disease Nexus Workshop Report March 22-23. Vancouver, Canada: Human Security Centre.

2005. Human Security Report 2005. Vancouver, Canada: Human Security Centre.

International Committee of the Red Cross (ICRC). 2001. Women Facing War. Geneva: ICRC.

Im, K., H. Pesaran, and Y. Shin. 2003. Testing for Unit Roots in Heterogeneous Panels. Journal of Econometrics 115 (1):53-74.

Jones, Adam. 1994. Gender and Ethnic Conflict in Ex-Yugoslavia. Ethnic and Racial Studies 17 (1): $115-34$

2000. Gendercide and Genocide. Journal of Genocide Research 2 (2):185-211.

. 2002. Gender and Genocide in Rwanda. Journal of Genocide Research 4 (1):65-94.

ed. 2004. Gendercide and Genocide. Nashville, Tenn.: Vanderbilt University Press.

Kennelly, Brendan, Eamon O'Shea, and Eoghan Garvey. 2003. Social Capital, Life Expectancy and Mortality: A Cross-National Examination. Social Science \& Medicine 56 (12):2367-77.

Keohane, Robert O. 1998. Beyond Dichotomy: Conversations Between International Relations and Feminist Theory. International Studies Quarterly 42 (1):193-98.

King, Gary, and Lisa L. Martin. 2001. The Human Costs of Military Conflict. Overview Paper for 
Conference on Military Conflict as a Public Health Problem, September, Cambridge, Mass.: Harvard University.

Krasner, Stephen D. 2004. Sharing Sovereignty: New Institutions for Collapsed and Failing States. International Security 29 (2):85-120.

Lacina, Bethany, and Nils Petter Gleditsch. 2005. Monitoring Trends in Global Combat: A New Dataset of Battle Deaths. European Journal of Population 21 (2/3):145-66.

Li, Quan, and Ming Wen. 2005. The Immediate and Lingering Effects of Armed Conflict on Adult Mortality. A Time-Series Cross-National Analysis. Journal of Peace Research 42 (4):471-92.

Marshall, Monty G., and Donna Ramsey. 1999. Gender Empowerment and the Willingness of States to Use Force. Working Paper. Severn, Md.: Center for Systemic Peace.

Mathers, Colin D., Ritu Sadana, Joshua A. Salomon, Christopher J. L. Murray, and Alan D. Lopez. 2001. Healthy Life Expectancy in 191 Countries, 1999. The Lancet 357 (9269):1685-91.

McKee, Martin. 1999. Alcohol in Russia. Alcohol and Alcoholism 34 (6):824-29.

Moser, Caroline O. N. 2001. The Gendered Continuum of Violence and Conflict. In Victims, Perpetrators or Actors? edited by Caroline O. N. Moser and Fiona C. Clark, 30-51. London: Zed Books.

Murdoch, James C., and Todd Sandler. 2002. Economic Growth, Civil Wars, and Spatial Spillovers. Journal of Conflict Resolution 46 (1):91-110.

Murray, Christopher J. L. 1994. Quantifying the Burden of Disease: The Technical Basis for DisabilityAdjusted Life Years. Bulletin of the World Health Organization 72 (3):429-45.

Murray, Christopher J. L., Gary King, Alan D. Lopez, N. Tomijima, and E. G. Krug. 2002. Armed Conflict as a Public Health Problem. British Medical Journal 324 (7333):346-49.

Neumayer, Eric. 2005. Bogus Refugees? The Determinants of Asylum Migration to Western Europe. International Studies Quarterly 49 (4):389-409.

Norwegian Refugee Council. 2002. Internally Displaced People: A Global Survey. London: Earthscan.

Pampel, Fred. 2003. Declining Sex Differences in Mortality from Lung Cancer in High-Income Nations. Demography 40 (1):45-65.

Plümper, Thomas, and Vera E. Troeger. 2004. Efficient Estimation of Rarely Changing Variables in Fixed Effects Models. Working Paper Series 622581. Social Science Research Network. Available at (www.ssrn.com). Accessed March 152006.

. 2005. Efficient Estimation of Time-Invariant and Rarely Changing Variables in Finite Sample Panel Analyses with Unit Fixed Effects. Paper presented at the American Political Science Association Conference, September, Washington, D.C.

Plümper, Thomas, Vera E. Troeger, and Philip Manow. 2005. Panel Data Analysis in Comparative Politics. Linking Method to Theory. European Journal of Political Research 44 (2):327-54.

Preston, Samuel H., Patrick Heuveline, and Michel Guillot. 2001. Demography-Measuring and Modeling Population Processes. Oxford, England: Blackwell.

Regan, Patrick M., and Aida Paskeviciute. 2003. Women's Access to Politics and Peaceful States. Journal of Peace Research 40 (3):287-302.

Reno, William. 2003. Sierra Leone: Warfare in a Post-State Society. In State Failure and State Weakness in a Time of Terror, edited by Robert I. Rotberg, 71-100. Washington, D.C.: Brookings Institution Press.

Roberts, Les, Riyad Lafta, Richard Garfield, Jamal Khudhairi, and Gilbert Brunham. 2004. Mortality Before and After the 2003 Invasion of Iraq: Cluster Sample Survey. The Lancet 364 (2):1857-64.

Rotberg, Robert I. 2002. Failed States in a World of Terror. Foreign Affairs 81 (4):127-40. Press.

Seifert, Ruth. 1994. War and Rape: A Preliminary Analysis. In Mass Rape: The War Against Women in Bosnia-Herzegovina, edited by Alexandra Stiglmayer and Marion Faber, 54-72. Lincoln: University of Nebraska Press.

Shoemaker, Jolynn. 2001. Women and Wars Within States: Internal Conflict, Women's Rights and International Security. Civil Wars 4 (3):1-34. 
Stiglmayer, Alexandra, and Marion Faber. 1994. Mass Rape: The War Against Women in BosniaHerzegovina. Lincoln: University of Nebraska Press.

Strand, Havard, Lars Wilhelmsen, and Nils Petter Gleditsch. 2004. Armed Conflict Dataset Codebook Version 2.1. Oslo: International Peace Research Institute Oslo and Uppsala University. Available at 〈www.prio.no/cscw/armedconflict). Accessed 15 March 2006.

Tickner, J. Ann. 1997. You Just Don't Understand: Troubled Engagements Between Feminists and IR Theorists. International Studies Quarterly 41 (4):611-32.

2001. Gendering World Politics: Issues and Approaches in the Post-Cold War Era. New York: Columbia University Press.

2005. What Is Your Research Program? Some Feminist Answers to International Relations Methodological Questions. International Studies Quarterly 49 (1):1-21.

Toole, Michael J. 1997. Displaced Persons and War. In War and Public Health, edited by Berry S. Levy and Victor W. Sidel, 197-211. New York: Oxford University Press.

Toole, Michael J., and R. J. Waldman. 1988. An Analysis of Mortality Trends Among Refugee Populations in Somalia, Sudan, and Thailand. Bulletin of the WHO 66:237-47.

United Nations (UN). 2000. Women, Peace and Security. Study submitted by the Secretary-General pursuant to Security Council Resolution 1325 (2000). New York: UN.

2002. Resolution $1325(2000)$ Adopted by the Security Council at Its 4213 th Meeting, on 31 October 2000. New York: UN.

2003. Consolidated Inter-Agency Appeal for the Democratic Republic of the Congo 2003, New York: UN, 16 January 2003.

United Nations Development Programme (UNDP). 2004. Human Development Report. New York: Oxford University Press.

United Nations Development Fund for Women (UNDFW). 2002. Women, War and Peace. New York: UNDFW.

U.S. Census Bureau. 2004. Global Population Profile 2002. Washington, D.C.: Government Printing Office.

Verwimp, Philip. 2003. Testing the Double-Genocide Thesis for Central and Southern Rwanda. Journal of Conflict Resolution 47 (4):423-42.

World Health Organization (WHO), 2004. Country Profile Bosnia and Herzegovina, Geneva: WHO. Various years. World Health Report. Geneva: WHO.

Williamson, John B., and Ulrike Boehmer. 1997. Female Life Expectancy, Gender Stratification, Health Status, and Level of Economic Development: A Cross-national Study of Less Developed Countries. Social Science \& Medicine 45 (2):305-17.

World Bank. 2004. World Development Indicators on CD-Rom. Washington, D.C.: World Bank. 
Copyright of International Organization is the property of Cambridge University Press / UK and its content may not be copied or emailed to multiple sites or posted to a listserv without the copyright holder's express written permission. However, users may print, download, or email articles for individual use. 